\title{
INTERTEXTUALITY IN INDONESIAN NEWSPAPER OPINION ARTICLES ON EDUCATION: ITS TYPES, FUNCTIONS, AND DISCURSIVE PRACTICE ${ }^{1}$
}

\author{
Anni Holila Pulungan \\ (anniholilapulungan@yahoo.com) \\ Universitas Negeri Medan, Indonesia \\ Edi D. Subroto \\ Sri Samiati Tarjana \\ Sumarlam \\ Universitas Sebelas Maret, Indonesia
}

\begin{abstract}
This research deals with intertextuality in opinion articles on education. Its objectives are to discover types and functions of intertextuality in the articles and to reveal its social practice. The results of the research reveal there are three major types and two major functions of intertextuality in the articles. The type dominantly applied is indirect quotation and the function dominantly applied is to provide things in detail. The social practice found in the articles is that the intertextuality is functioned to create an image that the articles possess a level of academic text.
\end{abstract}

Key words: intertextuality, discursive practice, discourse, newspaper, opinion article

One of features found in Indonesian newspapers is a space specifically dedicated to articles discussing ongoing issues in Indonesia. The topic covered

\footnotetext{
${ }^{1}$ Aside from BPPS Indonesian Government Scholarship, this research also receives research fund from the management of KOMPAS daily.
} 
by this feature varies and one of them is on educational issues, both nationally and regionally related issues. So, this feature becomes an open medium for its readers to discuss ongoing educational issues. However, it is also important to note that, to a certain degree, this feature is potential to influence the public opinion either to sustain or to challenge the current practice (Fairclough, 2003:9).

There are various linguistic aspects which may be investigated in such articles. One of them is its intertextuality. It is an aspect which has been least paid attention to. In fact, intertextuality is always present in any piece of writing (Chandler, 2002; Fairclough, 1992). Therefore, it is interesting to investigate the intertextuality in the opinion articles on education in Indonesian newspapers (hereafter mentioned as "the articles").

The term intertextuality has an extensive meaning and use. It is closely related to the term text itself. When the term text is understood in general semiotics, it may refer both linguistic and non-linguistic text. However, this study is focused on linguistic text and what is meant by intertextuality should be understood from the beginning as linguistic intertextuality then. The study itself is focused on investigating its types, functions, and discursive practice.

The term intertextuality was first coined by Julia Kristeva in 1967. The idea of intertextuality itself rooted in Bakhtin's works in Russian which had not been widely accessed until Kristeva discussed them in her doctoral thesis in 1966 (Graham, 2000). Intertextuality study originates in literary theory. It discusses how a literary work is related to prior literary works. Although intertextuality study originally appears in literary theory, this study has been applied in other disciplines such as discourse analysis, media studies, and social studies (Costello, 2007; Goellner, 2004; Agger, 1999; Mitra, 1999). Despite the growing interest in intertextuality study in text, it still remains an area of study which is least paid attention to in Indonesia.

The most basic notion of intertextuality is that texts do not appear in isolation, but surely in relation to other texts (Fairclough, 2003). What is meant by the term "text" in this study is restrictedly defined as a linguistic text which bears a certain social-interactional function. Indeed, texts comprising large body of paragraphs, such as opinion articles on newspapers, reveal explicitly its relation to other texts. They use resources provided by the prior text in their own text. Therefore, these texts are not more than an assemblage of the writer's own text and other writers' texts incorporated in his/her text. 
Intertextuality is not a matter of decorating a text with other texts and its application in a text does not bear any underlying meaning. It is not used by a writer only to illuminate his/her text without bearing a certain meaning. The use of intertextuality does have its meaning in text though the meaning itself is not consciously construed by the writer. Even, the reason stating that intertextuality is there because it is a common practice of a certain text indicates that there exists the meaning. The meaning being displayed there is that it is as common practice. Therefore, the meaning that emerges from the use of intertextuality in a text should be perceived differently from the lexical meaning of words.

The social meaning of intertextuality is construed in relation to a certain social practice to which a particular sort of text adhered. The behavior of how it is paradigmatically used across texts in the same genre is the major clue to disclose its social meaning. It is a kind of what Fairclough (1992:78) said as "discursive practice" which "involves processes of text production, distribution, and consumption, and the nature of the processes varies between different types of discourse according to social factors". A scientific journal article and a newspaper article, though both are written on the same topic area, certainly differ in many respects. What makes them to each other different is its discursive practice.

On the basis of what just previously explained, it is clear that this study is part of discourse analysis. What is meant by the term discourse here follows Fairclough (2003:3) as "the particular view of language in use.... as an element of social life which is closely interconnected with other elements”. A certain discourse is configured by series of texts which possess basic elements of distribution and consumption to share. The term discourse, then, refers to (i) series of texts which are in the same register and genre and (ii) series of texts which reveal a general and abstract portrait. It is generally considered to be in length discussion on register and genre (see for their discussion, Eckert and Rickford, 2001; Swales, 1990).

People may talk about "a discourse of educational advertisement". They certainly talk about series of advertisement texts concerning with education. However, they do not talk only about the number of the texts, but also most importantly features shared by those texts. Since each feature brings with it a social-interactional meaning, its discursive practice constitutes its social practice. On the basis of the discursive practice of certain features, then, people 
may talk about "a commercialization discourse in education" for instance (Fairclough, 2003).

Upon the basis of how intertextuality comes in to the articles, I notice that basically there are four features in intertextuality which discursively display its social meaning. Those are, as a matter in fact, the processes involved in incorporating other texts into a text. These four processes have something to do with what and why a writer select a certain choice than the others. These four processes are, firstly, how a writer incorporates other text into his/her text. Secondly, it is how the writer highlights the other texts in his/her text. Thirdly, it deals with the source from which the writer excerpts the text being intertextualized. And, finally, it is related to the textual function which is fulfilled by the intertextuality in the text.

\section{METHOD}

This study, as previously mentioned, is a discourse analysis. Based upon the theoretical perspective outlined in the prior part, the following is the concise method of discourse analysis to be applied in this study. In general, this method follows the model of discourse analysis which has been purposed by Fairclough (1992, 2003). It commenced with the analyses of texts to find out the features of intertextuality. It resulted in finding out the types and the functions on intertextuality in the articles. Next analysis was putting those features of intertextuality into a configuration which brought together its bits and pieces from each text into readable figure. This is basically the analysis of the discursive practice of intertextuality. Hence, the analysis of discursive practice is analyzing the behavior of intertextuality across texts in a certain discourse. Finally, the behavior of intertextuality was analyzed to figure out what sort of social practice is reflected and underlies the nature of its behavior.

The study investigates newspaper articles the topic of which has something to do with education. These articles go in a fixed place in each newspaper to be studied. Roughly they are placed in a column which is specially prepared to publish readers' opinions. The data of the study are presented in Table 1. 
Pulungan, Subroto, Tarjana, \& Sumarlam, Intertextuality in Indonesian Newspaper 141

Table 1. Data of the Study

\begin{tabular}{|c|c|c|c|c|}
\hline No & Newspaper & Location & Scope/ Region & $\begin{array}{l}\text { Column's } \\
\text { Name }\end{array}$ \\
\hline 1. & $\begin{array}{l}\text { Kompas } \\
\left(\text { KOM }^{* *}\right)\end{array}$ & Jakarta & National & $\begin{array}{l}\text { Opini “Opi- } \\
\text { nion” }\end{array}$ \\
\hline 2. & $\begin{array}{l}\text { Waspada } \\
\text { (WAS**) }\end{array}$ & Medan & Regional/ WPI* & $\begin{array}{l}\text { Opini } \\
\text { "Opinion" }\end{array}$ \\
\hline 3. & $\begin{array}{l}\text { Pikiran Rakyat } \\
\text { (PIR**) }\end{array}$ & Bandung & Regional/ WPI & $\begin{array}{l}\text { Opini } \\
\text { "Opinion" }\end{array}$ \\
\hline 4. & $\begin{array}{l}\text { Kedaulatan Rakyat } \\
\left(\mathrm{KER}^{* *}\right)\end{array}$ & Yogyakarta & Regional/ WPI & $\begin{array}{l}\text { Kolom } \\
\text { "Column" }\end{array}$ \\
\hline 5. & $\begin{array}{l}\text { Suara Merdeka } \\
\left(\text { SUM }^{* *}\right)\end{array}$ & Semarang & Regional/ WPI & $\begin{array}{l}\text { Wacana } \\
\text { "Discourse" }\end{array}$ \\
\hline 6. & $\begin{array}{l}\text { Fajar } \\
(\text { FAJ**) }\end{array}$ & Ujung Pandang & Regional/ MPI* & $\begin{array}{l}\text { Kolom } \\
\text { "Column" }\end{array}$ \\
\hline
\end{tabular}

Note. *WPI, Western Part of Indonesia; MPI, Middle Part of Indonesia; ** three initial alphabets will be used throughout the paper to substitute the name of the newspaper.

Some newspapers publish the articles on education on a regular basis. SUM, for instance, publish articles on education on Mondays; meanwhile, WAS on Fridays. The others do not publish them on such regular basis. Therefore, ten articles from each newspaper cannot be obtained from the same range in a short term. This problem is overcome by extending the range of term. The data were collected from the publication range $2004-2006$.

\section{FINDINGS AND DISCUSSION}

\section{General Result of Intertextuality Analysis in Numbers}

There are 3, 236 sentences from 60 articles that have been analyzed. Out of those sentences, there are 639 sentences considered to be intertextuality. It makes up $19.75 \%$ in average. The data analysis also reveals that intertextuality exists in every newspaper. The result of analysis can be summarized in Table 2. 
Table 2. The Result of Intertextuality Analysis in Numbers

\begin{tabular}{ccccccc}
\hline No. & $\begin{array}{c}\text { News- } \\
\text { paper }\end{array}$ & $\begin{array}{c}\text { Number of } \\
\text { Sentence }\end{array}$ & $\begin{array}{c}\text { Number } \\
\text { of Inter- } \\
\text { text-uality }\end{array}$ & $\begin{array}{c}\text { Number of } \\
\text { Non- } \\
\text { intertext- } \\
\text { uality }\end{array}$ & $\begin{array}{c}\text { Intertext- } \\
\text { uality (\%) }\end{array}$ & $\begin{array}{c}\text { Non- } \\
\text { Intertext- } \\
\text { uality (\%) }\end{array}$ \\
\hline 1 & KOM & 412 & 81 & 331 & 19.66 & 80.34 \\
2 & WAS & 582 & 178 & 404 & 30.58 & 69.42 \\
3 & PIR & 623 & 146 & 477 & 23.43 & 76.57 \\
4 & SUM & 558 & 88 & 470 & 15.77 & 84.23 \\
5 & KER & 451 & 81 & 370 & 17.96 & 82.04 \\
6 & FAJ & 610 & 65 & 545 & 10.66 & 89.34 \\
\hline & Total & 3,236 & 639 & 2,597 & 19.75 & 80.25 \\
\hline
\end{tabular}

\section{Types of Intertextuality}

The data analysis results in three types of intertextuality, i.e. (i) transtextuality, (ii) metatextuality, and (iii) pseudo-textuality. Transtextuality is the term used in this study to refer a type of intertextuality whose text being intertextualized is realized overtly in the articles. In other words, the text being intertextualized can be pointed out in the articles. Transtextuality in the articles is also realized in three types, (i) Citation, (ii) Quotation, and (iii) Allusion. Citation is a type of transtextuality whose source is located in brackets as in (1).

(1). Dalam bunyi pada UU Guru-dosen tersebut, definisi, batasan dan indikator terminologi "profesional", belum jelas benar, kecuali batasanbatasan leksikal yang dipahami sebagai tugas, jabatan, fungsi, dan kewenangan seseorang dilakukan dengan nilai-nilai profesi (Dj. Drost, 2004). (SUM-Article\#7)

"In Act on Teacher and Lecture, the definition, limitation, and indicator of the term "professional", are not yet clear except its lexical limitation which is understood as someone's duty, position, function, and authority in relation to professional values (Dj. Drost, 2004)”. 
What is put in the brackets " $\mathrm{Dj}$. Drost, 2004" in (1) is the speaker of the text being intertextualized. Citation (1) can be paraphrased as " $\mathrm{Dj}$. Drost says that in Act on Teacher and Lecture, the definition ......... values". This paraphrase reveals clearly which part constitutes the source and which part constitutes the text being intertextualized. It also clearly confirms that Citation be transtextuality.

Quotation refers to a type of transtextuality which may fall into (i) direct quotation or (ii) indirect quotation. Direct quotation and indirect quotation are identified based on orthographic marker "quotation marks" and source's voice which links the source with his/her text. Both can be seen in (2).

(2). a. Direct Quotation

Dalam ungkapan Martin, “Jumlah pakar komunikasinya kedua terbesar setelah jumlah pakar komunikasi AS”. (PIR-Article\#4)

"In Martin's expression, "The communication experts are the second biggest in number after those in USA"."

b. Indirect Quotation

Sebelum bangsa ini berdiri kokoh, Ki Hadjar Dewantara tahun 1936 telah mengajak masyarakat melakukan mobilisasi intelektual memberantas buta aksara. (KOM-Article\#6).

"Before this nation was firmly established, Ki Hajar Dewantara in 1936 had invited the people to mobilize intellectuality to fight against illiteracy."

Allusion is a type of transtextuality whose presence in the articles is implicit. It can be realized as Implicit Quotation, Negation, or Framing. Implicit Quotation is a type of Allusion whose source of its text is not presence. Negation is a type of Allusion which is identified on the basis of the presence of intertextual negation. And, Framing is a type of Allusion which is related to the transfer of semantic domain. The examples are presented in (3).

(3) a. Implicit Quotation

Ada usulan kuat perlunya memperbaiki tingkat penghasilan guru - termasuk di dalamnya dosen - agar kinerja tenaga kependidikan berada pada tingkat optimal, yang akhirnya bermuara pada tingkat kualitas pendidikan. (SUM-Article\#2) 
"There is strong proposal that it is necessary to improve the teachers' salary - including lecturers' salary - so that the performance of teaching staff is at optimal level which may result in the quality of the education.”

b. Negation

Perbedaan jenjang dan beban tanggung jawab tugas berikut konsekuensinya juga dapat secara formal diatur melalui peraturan pemerintah sehingga tidak perlu terjadi pro-kontra yang secara dikotomis memposisikan guru dan dosen pada jurang dan perbedaan yang sangat tajam. (PIR-Article\#2)

"The discrepancy between the level of position and the duty responsibility and also all its consequences shall be formally regulated by government's regulation so that there should have not be pros-cons which situate teachers and lecturers in opposite polar and in such sheer discrepancy.”

\section{c. Framing}

Mereka membuat anak didik menjadi beo. (KOM-Article\#6)

"They make the students be parrots."

(3.a) is called as a quotation because it poses one of the features of Quotation, i.e. the presence of the intertextual voice "usulan, mengusulkan" (proposal, to propose). In fact, the source to which the text being intertextualized referred is not present. Therefore, it is not reckoned as Quotation though partly it resembles a quotation. The source from where the text was quoted has to be present if it is a quotation. That is why it is called Implicit Quotation.

The text being intertextualized in (3.b) is also not represented explicitly. That there is intertextuality can be explained by the presence of negation which functions to reject a linguistic text which has been produced. The negation in (3.b) indicates implicitly that pros-cons concerning lecturers and teachers have prevailed. Here the presence of intertextuality is identified on the basis of the presence of intertextual negation, i.e. negation which functions to intertextualize other texts into a text.

Metatextuality refers to a type of intertextuality whose text being intertextualized is realized covertly in the the articles. On contrary to transtextuality, this means that the text being intertextualized is outside the articles. There are two types, (i) metatextuality which the text being intertextualized is still exter- 
Pulungan, Subroto, Tarjana, \& Sumarlam, Intertextuality in Indonesian Newspaper 145

nal and (ii) metatextuality which the text being intertextualized can be referred to the previous sentences. The example of Metatextuality can be seen in (4).

(4). a. Mahasiswa sendiri memiliki pandangan yang berbeda-beda terhadap kegiatan ini. (PIR-Article\#1)

"Students themselves have different opinions on this activity."

b. Usulan lebih realistis tersebut dapat digunakan pada jenjang kepangkatan guru. (SUM-Article\#2)

"More realistic proposal may be applied to the level of teachers' position.”

Data (4) are metatextuality because the texts being intertextualized are not present there overtly. The intertextuality is perceived on the basis of the presence of the intertextual voices. Those are "memiliki pandangan" (to have opinion) for (4.a) and "usulan" (proposal) for (4.b). It is understood that there are different opinions but the different opinions themselves are not present and that there is a proposal but the content of the proposal itself is not present. (4.a) is the example of metatextuality which still lies outside the text. Meanwhile, (4.b) is the example of metatextuality which can be referred to the previous text. When the metatextuality still lies outside, it means that the content of the intertextuality is not important.

The texts which are being intertextualized in the form of metatextuality may be presented or represented as in (5).

(5). a. Mahasiswa sendiri berpendapat secara berbeda-beda (opinion 1, opinion 2, opinion 3, etc) terhadap kegiatan ini.

"Students themselves have different opinions (opinion 1, opinion 2, opinion 3, etc.) on this activity.”

b. (Sumber) mengusulkan (sesuatu). (Sesuatu) lebih realistis tersebut dapat digunakan pada jenjang kepangkatan guru.

“(Source) proposes (something). (That something) more realistic may be applied to the level of teachers' position.”

Finally, the term pseudo-textuality refers to a type of intertextuality which textually implies the presence of other texts in the articles; in fact, it is not really part of intertextuality. The example can be seen in (6). 
(6). a. Kita berharap, apabila tunjangan itu disetujui DPR, para guru akan melaksanakan peran dan fungsinya sebagai pendidik secara lebih bertanggung jawab. (KOM-Article\#5)

"We hope, in case that the additional income is agreed by People's Representatives, that teachers will play their roles and functions as educators in more responsible manner.

b. ... kita berbicara tentang peningkatan kualitas guru, sertifikasi mengajar dan sebagainya. (KER-Article\#9)

“... we talk about the improvement of teachers' quality, teaching certification, and so on.”

Pseudo-transtextuality as presented in (6) is a typical type of intertextuality in Indonesian text and shall be discussed in a separate study. It is never discussed in any intertextuality study since the tradition of intertextuality study is in English. This type of intertextuality is related to the use of pronoun "kita", referring inclusively to the first singular/plural person(s) and the second singular/plural person(s). Though it may be possible also in English, it tends to occurs much more in Indonesian than in English. This is called 'pseudo' since there seems to be intertextuality but, in fact, there is no intertextuality. It is a matter of cultural use of pronoun in Indonesian. It sounds polite to include the interlocutor when one is speaking.

\section{The Functions Fulfilled by Intertextuality in The Articles}

That each intertextuality has a certain social-interactional function in the articles has been in the theory. The analysis reveals that there are ten functions fulfilled by intertextuality in the articles. Those functions can be grouped on the basis of whether a function is related to the topic being discussed in the articles as a whole or to a certain idea posed by a sentence in the articles. The former is intertextuality which is used to fulfill "topical function" (hereafter, TOFU). The latter is intertextuality which used to fulfill "inter-sentential function” (hereafter, ISFU).

In general, both TOFU of intertextuality and ISFU of intertextuality has five functions. TOFU comprises function (i) to introduce the articles's topic, (ii) to introduce the articles's sub-topic, (iii) to conclude the articles's discussion, (iv) to provide suggestion, and (v) to conclude the articles's sub-topic. 
Those five functions obviously are related to the topic discussed in the articles as a whole. Meanwhile, the five functions of ISFU are (i) to provide a contradictory statement, (ii) to provide additional explanation, (iii) to provide data, (iv) to provide examples, (v) to describe data. These functions of ISFU are related to a certain part of the articles not the articles as a whole. The result of analysis of intertextuality functions can be presented in Figure 1.

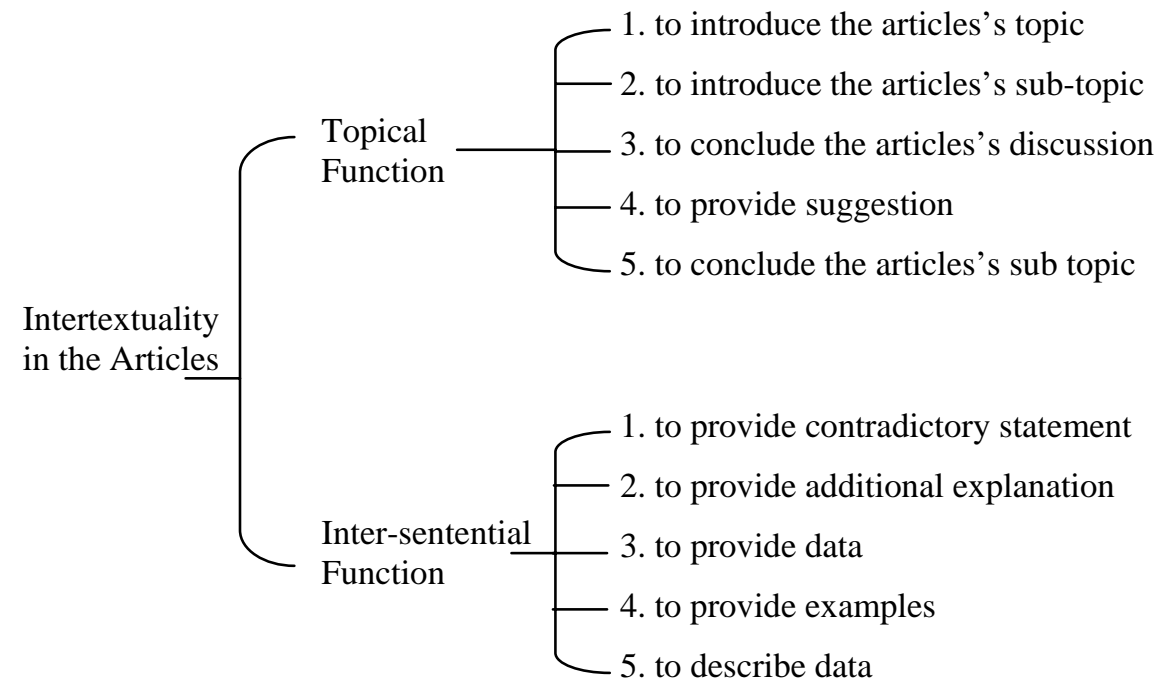

Figure 1. Intertextuality Function in the Articles

\section{The Discursive Practice of Intertextugality Functions in the Articles}

The macro level of analysis indicates that texts being intertextualized in the articles are functioned to fulfill both TOFU and ISFU. The general functions fulfilled by texts being intertextualized in the articles are presented in Table 3 . 
Table 3. General Functions of Texts being Intertextualized in the Articles

\begin{tabular}{lccccccc}
\hline Functions & KOM & WAS & PIR & SUM & KER & FAJ & $\begin{array}{c}\text { Average } \\
\%\end{array}$ \\
\hline $\begin{array}{l}\text { Number of TOFU } \\
\text { \%) }\end{array}$ & 30.86 & 14.04 & 8.22 & 7.95 & 11.11 & 12.31 & 13.36 \\
Number of ISFU (\%) & 69.14 & 85.96 & 91.78 & 92.05 & 88.89 & 87.69 & 86.64 \\
\hline
\end{tabular}

It is obvious that intertextuality used to fulfill ISFU is much more than that used to fulfill TOFU. Intertextuality used to fulfill ISFU reaches $13.36 \%$ in average and intertextuality used to fulfill TOFU reaches $86.64 \%$ in average. In other words, intertextuality tends to be used to react against a partial discussion in the articles.

\section{Inter-sentential Function}

Out of five functions of ISFU, function "to describe data" is the function which is mostly embedded to texts being intertextualized in the articles. The subsequent functions which are mostly given to intertextuality are function "to provide additional explanation" and function "to provide data". The result of data analysis of ISFU is presented in Table 4.

Table 4. Number and Percentage of Intertextuality in ISFU.

\begin{tabular}{|c|c|c|c|c|}
\hline & & Function & Number & (\%) \\
\hline \multirow{5}{*}{ 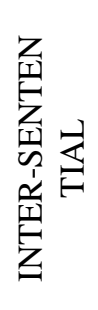 } & 1 & to provide contradictory statement & 63 & 11.39 \\
\hline & 2 & to provide additional explanation & 159 & 28.75 \\
\hline & 3 & to provide data & 152 & 27.49 \\
\hline & 4 & to provide examples & 11 & 1.99 \\
\hline & 5 & to describe data & 168 & 30.38 \\
\hline & & Total & 553 & 100 \\
\hline
\end{tabular}


Table 4 shows how texts being intertextualized in the articles are discursively functioned in ISFU. This indicates that the discursive practice of intertextuality function in the articles is related to "things in detail" and particularly to "data presentation". What is obvious here is that the writer of the articles brings other texts into his/her text when he/she is confronted with the data and additional explanation of the problem being discussed in the articles. This discursive practice is a practice of incorporating others' opinion into the articles.

Bringing others' voice into one's own text is a standard practice in academic text. The aim of this practice is not to illuminate the articles with others' expression but, most importantly, to bring authoritative voices into the articles. Therefore, when data presentation and explanation are based on authoritative voices, it means that the writer of the articles presents a credible data and its explanation. This social practice underlying this practice is to create an academic sense in the articles.

\section{Topical Function}

Intertextuality which is used in TOFU spreads more evenly across the five functions. How intertextuality used in TOFU can be summarized in Table 5.

Table 5. Number and Percentage of Intertextuality in TOFU.

\begin{tabular}{|c|c|c|c|c|}
\hline \multicolumn{3}{|c|}{ Function } & \multirow{2}{*}{$\begin{array}{c}\text { Number } \\
24\end{array}$} & \multirow{2}{*}{$\begin{array}{c}(\%) \\
27.91\end{array}$} \\
\hline \multirow{5}{*}{$\begin{array}{l}\text { 岕 } \\
\underline{U} \\
0 \\
0 \\
0\end{array}$} & 1 & to introduce the articles's topic & & \\
\hline & 2 & to introduce the articles's sub-topic & 20 & 23.26 \\
\hline & 3 & to conclude the articles's discussion & 14 & 16.28 \\
\hline & 4 & to provide suggestion & 12 & 13.95 \\
\hline & 5 & to conclude the articles's sub topic & 16 & 18.60 \\
\hline & & Total & 86 & 100 \\
\hline
\end{tabular}

Out of the five functions in TOFU, function "to introduce the article's topic" is mostly given to intertextuality. This indicates that the issues being discussed in the articles mostly are related to the issues which have emerged previously. Even, four out five functions in TOFU are concerned with introducing and concluding topic being discussed in the articles. This discursive practice 
implies that the articles, and presumably newspaper articles on other scope of problems, are texts whose issues discussed in it are dynamic in nature. They are related one to each other as a medium of public discussion.

\section{Function and Types of Intertextuality}

It has been mentioned previously that the social practice underlying the discursive practice of ISFU is making an academic sense in the articles. This sounds that the articles is a kind of academic text. Are the articles a kind of academic text?

Data analysis reveals that Indirect Quotation is dominantly used in the articles. Its use in the articles reaches up to $75 \%$ as in Table 6.

Table 6. The Use of Types of Intertextuality

\begin{tabular}{|c|c|c|c|c|c|c|c|c|c|}
\hline \multirow{3}{*}{ No } & \multirow{3}{*}{$\begin{array}{l}\text { News- } \\
\text { paper }\end{array}$} & \multicolumn{6}{|c|}{ Transtextuality (\%) } & \multirow{3}{*}{$\begin{array}{c}\text { Meta- } \\
\text { text- } \\
\text { uality }\end{array}$} & \multirow{3}{*}{$\begin{array}{l}\text { Pseudo- } \\
\text { textuality }\end{array}$} \\
\hline & & \multirow{2}{*}{$\begin{array}{l}\text { Cita- } \\
\text { tion }\end{array}$} & \multicolumn{2}{|c|}{ Quotation } & \multicolumn{3}{|c|}{ Allusion } & & \\
\hline & & & $\begin{array}{l}\text { Di- } \\
\text { rect }\end{array}$ & $\begin{array}{c}\text { In- } \\
\text { direct }\end{array}$ & $\begin{array}{l}\text { Im- } \\
\text { plicit }\end{array}$ & $\begin{array}{c}\mathrm{Ne}- \\
\text { gation }\end{array}$ & $\begin{array}{l}\text { Fra- } \\
\text { ming }\end{array}$ & & \\
\hline 1 & KOM & 18.52 & 0.00 & 49.38 & 3.70 & 0.00 & 28.40 & 0.00 & 0.00 \\
\hline 2 & WAS & 0.56 & 13.48 & 84.83 & 0.00 & 0.00 & 0.56 & 0.56 & 0.00 \\
\hline 3 & PIR & 4.79 & 8.22 & 76.71 & 2.74 & 0.68 & 2.05 & 3.42 & 1.37 \\
\hline 4 & SUM & 7.95 & 0.00 & 76.14 & 3.41 & 0.00 & 9.09 & 3.41 & 0.00 \\
\hline 5 & KER & 6.17 & 0.00 & 82.72 & 4.94 & 0.00 & 6.17 & 0.00 & 0.00 \\
\hline 6 & FAJ & 9.23 & 6.15 & 69.23 & 1.54 & 0.00 & 10.77 & 1.54 & 1.54 \\
\hline \multicolumn{2}{|c|}{ Average \% } & 6.42 & 6.26 & 75.43 & 2.35 & 0.16 & 7.36 & 1.56 & 0.47 \\
\hline
\end{tabular}

In fact, Indirect Quotation used in the articles as presented in (2.b) is different from the way it is used in academic text. It is a pure indirect quotation which differs from that in an academic text which is partly Citation. In academic text, it is not only authoritative voice which is necessary but also the traceability of its source. Therefore, Indirect Quotation in the articles only bears the authority side of quotation as an academic feature. It does not bear the traceability side of quotation as an academic feature which surely has to be put in the Citation form. 
This discursive practice bridges the necessity of academic feature in the articles and that of being informal in public sphere. Making data presentation and explanations sound authoritative obviously requires an academic sense. This is obtained by bringing authoritative voice from outside into the articles. An academic text uses Citation to realize it. In fact, the articles is not in an academic setting. The sense of academic in the articles is reduced by dropping the traceability feature and applying Indirect Quotation.

\section{CONCLUSION}

This study shows briefly three major types of intertextuality which possibly emerge in Indonesian texts. Those are transtextuality, metatextuality, and Quasi-textuality. Transtextuality is dominantly used in the articles. Out of six sub-types of transtextuality, Indirect Quotation is the dominant one. The social practice underlying the discursive practice of intertextuality in the articles is putting an academic sense in newspaper article. Therefore, though the articles is in public sphere and not in an academic setting, the articles holds an academic feature which makes it sound authoritative discussion.

This conclusion constitutes only a small part of the intertextuality study in the articles. It will be more comprehensive if various discursive practices are studied. The discursive practices which are required to deepen the conclusion are such as the discursive practice of the topics discussed in the articles, that of the writers, that of sources brought into the articles, and that of how the relation between sources and their texts are bounded in the articles to mention some.

\section{REFERENCES}

Agger, G. 1999. Intertextuality Revisited: Dialog and Negotiations in Media Studies. Canadian Aesthetics Journal/Revue Canadienne d'esthetique. Volume 4.

Graham, A. 2000. Intertextuality (The New Critical Idiom). London: Routledge

Chandler, D. 2002. Semiotics: The Basics. London: Routledge 
Costello, M. 2007. Textuality, Mutability and Learning to Write. Journal of Text. Vol. 11 No. 2. Retrieved September 2009 from http://www.textjournal.com.au

Eckert, P. \& John, R. R. 2001. Style and Sociolinguistic Variation. Cambridge: CUP

Fairclough, N. 2003. Analyizing Discourse: Textual Analysis for Social Research. London: Routledge.

Fairclough, N. 1995. Critical Discourse Analysis, the Critical Study of Language. London: Longman.

Fairclough, N. 1992. Discourse and Social Change. Cambridge: Polity Press.

Genette, G. 1997. Palimpsests - Literature in the Second Degree. Nebraska: University of Nebraska Press.

Goellner, S. 2004. Assia Djebar and Eugene Fromentin's Haoua: Cultural Betrayal and Intertextual Transformation. A Graduate Journal of French and Francophone Studies. Retrieved September 2009 from http://www.brown.edu/Research/ Equinoxes/journal/eqx2_index.html

Mitra, A. 1999. Characteristics of the WWW Text: Tracing Discursive Strategies. Journal of Computer-Mediated Communication. Vol.5, Issue 1. Retrieved October 2009 from http://jcmc.indiana.edu/vol5/issue1/mitra.html

Swale, J. M. 1990. Genre Analysis, English in Academic Setting and Research Settings. Cambridge: CUP 